\title{
1 Prevalence and characteristics of jaguar trade in north-western Bolivia
}

2 Melissa Arias $^{1 *}$, Amy Hinsley ${ }^{1}$, Paola Nogales-Ascarrunz ${ }^{2}$, Nuno Negroes ${ }^{3}$, Jenny A. Glikman ${ }^{4}$, E.J.

$3 \quad$ Milner-Gulland ${ }^{1}$

4

$5 \quad{ }^{1}$ Department of Zoology, University of Oxford, Zoology Research and Administration Building, 11a

6 Mansfield Road, Oxford, OX1 3SZ

$7 \quad{ }^{2}$ Carrera de Biología - Universidad Mayor de San Andres, 27 st. Cota Cota, La Paz, Bolivia

$8 \quad{ }^{3}$ CESAM \& Biology Department, Aveiro University, Campus de Santiago, 3810-193, Aveiro-Portugal

9 and ACEAA-Conservación Amazónica, La Paz, Bolivia

$10{ }^{4}$ Instituto de Estudios Sociales Avanzados (IESA-CSIC), Campo Santo de los Mártires 7, 14004

11 Córdoba, Spain

12 *Corresponding author contact: melissa.arias@zoo.ox.ac.uk/melissaariasg@gmail.com 


\section{Abstract}

14 Recent seizures of jaguar body parts in Bolivia have prompted concern about illegal trade to China,

15 but concrete evidence is lacking. We interviewed 1107 people in a rural area implicated in the trade, 16 using direct and indirect questions to explore the prevalence and characteristics of jaguar trade and

17 its links to foreign demand. Jaguar trade is a common, non-sensitive practice; $46 \%$ of respondents

18 reported some involvement over the past 5 years. Up to $31 \%$ of respondents owned jaguar body

19 parts, most commonly skins, fat and teeth for decorative, medicinal, and cultural purposes. Contrary

20 to expectations, Bolivians were the most reported traders, and presence of Caucasian traders was

21 significantly and positively associated with jaguar trade, ahead of Asian and regional traders. Overall,

22 jaguar trade in Bolivia has more diverse drivers than seizures may suggest. Therefore, conservation

23 interventions, in addition to targeting Chinese demand, should address foreign and domestic trade 24 chains. 
Illegal wildlife trade (IWT) is among the most pressing threats to biodiversity. Due to IWT's concealed nature, those working to address it must often make decisions under high levels of uncertainty ( $T$ Sas-Rolfes et al. 2019). However, given its complex local and global drivers, strategies to address IWT should be rooted in cross-scale evidence in order to be effective (Milner-Gulland et al. 2018). This is particularly important in the case of wild felids, many of which are highly threatened by IWT due to domestic and international demand for their body parts (Nijman et al. 2019), adding to the pressures that they face from habitat loss and prey depletion (Macdonald \& Loveridge 2010). The illegal trade in tiger (Panthera tigris) bones and other body parts to supply Asian traditional medicine markets is of particular concern, having caused precipitous declines in wild tiger populations (Sanderson et al. 2010; Nowell 2010; Davis et al. 2020).

The trade in tiger parts is also having repercussions for other felids that act as tiger substitutes (Villalva \& Moracho 2019). Since 2008, there has been an increase in legal exports of lion (Panthera leo) bones from captive-breeding facilities in South Africa to Asia for medicinal purposes (Williams et al. 2017b). Similarly, leopards (Panthera pardus), clouded leopards (Neofelis sp.) and snow leopards (Panthera uncia) are being hunted or commercially bred to meet Chinese demand in addition to local traditional uses (D’Cruze \& Macdonald 2015; Coghlan et al. 2015; Stein et al. 2016). Since 2013, seizures of jaguar (Panthera onca) body parts destined for China in countries like Bolivia and Surinam suggest that Chinese demand for felids has reached Latin America (Nunez \& Aliaga-Rossel 2017; Verheij 2019). Most of the seizures involved jaguar teeth, but others included 'jaguar paste', a suspected alternative to tiger paste in traditional Asian medicines (Lemieux \& Bruschi 2019). Key players implicated in these seizures were Chinese long-term immigrants and recently arrived company workers, employed in numerous extractive industries in Latin America (Verheij 2019). 
However, despite the current attention to Chinese demand for jaguar body parts, jaguar hunting and trading at the domestic level for cultural, commercial and safety reasons is longstanding and significant. Symbolizing war, kingship, and status, jaguars were traded across long distances by Latin American indigenous societies as early as the Pre-Ceramic Age (ca. 500 BC to AD 600) (Laffoon et al., 2014). Throughout most of the $20^{\text {th }}$ century, thousands of rural communities in Latin America based their livelihoods on the commercial trade in jaguar skins for the occidental fashion industry (Matos \& Caldarelli 2017). Although jaguar trade officially ended in 1975 with their listing on Appendix I of the Convention on International Trade in Endangered Species of Wild Fauna and Flora, jaguar killing and trading continued in retaliation for livestock depredation and to supply households and craft markets with decorative, spiritual and medicinal jaguar-based products (Castaño-Uribe et al. 2017; Jędrzejewski et al. 2017; WCS. 2019).

60

Like other countries in the region, jaguar killing is common in rural Bolivia (Knox et al. 2019). However, since 2013, Bolivia has become the epicentre of body part seizures linked to Chinese demand (Nunez \& Aliaga-Rossel 2017). This has led to growing concern that profit-driven targeted killing of jaguars to supply foreign felid body part markets may be a leading threat to jaguars in the country. However, the relationship between jaguar killing, domestic use and the international trade in felids remains poorly understood, as are the prevalence and characteristics of jaguar trade in Bolivia. Policies and interventions to address jaguar trade are being drafted and implemented at the domestic and international levels; it is important that these are based on evidence from source areas, rather than solely on seizures that risk misrepresenting the trade. Here, we report on a study of jaguar trade in rural communities in north-western Bolivia, in which we explored the prevalence and characteristics of people's engagement with jaguar killing and trading, focusing on their links to Chinese demand and other foreign and local markets. 


\section{Methods:}

\subsection{Study site and participant selection:}

Within Bolivia, we selected areas with jaguar presence and reported cases of jaguar killing or trading, where livestock ranching or hunting are common livelihood activities, and where there are current or recent Chinese infrastructure investments (Fig 1). While the specifics are not transferable beyond these locations, our study examines the role of Chinese demand in an area with a long and currently active history of interactions between humans and jaguars. We randomly sampled villages with populations of 250-2000 inhabitants, within $150 \mathrm{~km}$ of the main urban areas, and semi-randomly chose households for interviewing (Appendix S1).

\subsection{Survey Instrument and Questioning Techniques}

We showed participants photos of all felids present in our study area, and highlighted repeatedly that our focus was on the jaguar (including the melanistic variant). As part of a larger survey, we asked participants eight direct yes/no questions concerning their engagement with jaguar killing and trading, along with semi-structured questions on the methods used to kill jaguars, the body parts that are traded and their uses, their awareness of the law regarding jaguar killing, and their knowledge about local and foreign traders. In addition to direct questions, we tested the Ballot Box Method (BBM), aiming to reduce social desirability bias in participants' responses and explore the sensitivity of the issue. The BBM requires participants to give their answer secretly by marking a ballot with "yes" or "no" and placing it inside a sealed ballot box (Bova et al. 2018). We chose the BBM after conducting a pilot study $(n=100)$ in Pando, involving other sensitive questioning techniques including the Randomized Response Technique, Crosswise Technique, Unmatched Count Technique and Nominative Technique (Nuno \& St. John 2015). The survey, which was conducted 
from June to August 2019, took 20 to 40 minutes to complete, and was carried out by a team of five Bolivian and international researchers with experience investigating human-jaguar interactions.

\subsection{Data analysis}

We calculated the prevalence of jaguar killing and trading actions by obtaining the proportion of 'yes' to 'no' answers for each action, removing missing responses. We estimated $95 \%$ confidence intervals using package 'prevalence' (Devleesschauwer et al. 2014) in R version 3.6.2 ( $R$ Core Team 2019). For each question, we identified participants who admitted to an action using the BBM but not in direct questioning (an indication of the sensitivity of the question) and vice versa (an indication of non-adherence to the instructions of the BBM). We used binomial GLMs using the package 'stats' (R Core Team 2019) to compare the effects of using the BBM and direct questioning and examine the factors associated with differing responses between the methods. To determine the association of presence of traders with jaguar killing and trading actions, we applied mixed effects binomial GLMs using package 'Ime4' (Bates et al. 2015), with community within study area as random effects.

\section{Results}

\subsection{Jaguar killing and trading prevalence}

We interviewed 1107 people across our four study areas, with varying socioeconomic characteristics (Table S2). Forty-six percent of our sample had personally engaged with jaguar trade in some way during the past 5 years (Figure 2). Additionally, $6 \%$ of participants stated that their partners had engaged in jaguar killing or trading in the past 5 years, and $9 \%$ that they had themselves done so more than 5 years ago. The most prevalent activity was owning jaguar body parts, followed by being asked to kill a jaguar and asking others to kill a jaguar. Killing, selling, and buying jaguars were less 
prevalent, while raising a live jaguar, and killing more than five jaguars were the least common actions. There were no statistically significant differences in the prevalence of jaguar killing and trading actions between study areas, with the exception of owning jaguar body parts, which was significantly higher in Trinidad (OR $2.56,95 \% \mathrm{Cl} 1.06-6.15, \mathrm{p}<0.05)$ than in the other study regions.

\subsection{BBM versus Direct Questioning}

The BBM resulted in a higher prevalence of all jaguar killing and trading actions than direct questioning; averaging across actions, $6.7 \%$ of respondents admitted to actions through the BBM but not directly, suggesting they found the question sensitive. However, the only action for which the BBM led to a significantly higher prevalence than the direct question was asking others to kill a jaguar (OR 3.27, 95\% $\mathrm{Cl} 2.17-4.97, \mathrm{p}<0.001$ ). Older participants were less likely to find the questions sensitive (OR 0.99, $95 \% \mathrm{Cl} 0.97-1.00, \mathrm{p}<0.01)$, contrary to those with agricultural livelihoods (OR 1.49, $95 \% \mathrm{Cl} 1.05-2.12, \mathrm{p}<0.05)$. Participants who did not know the legal status of jaguars were less likely to find questions sensitive $(\mathrm{OR} 0.37,95 \% \mathrm{Cl} 0.31-0.43, \mathrm{p}<0.001)$ than those who were aware of their protected status. A small number of respondents (4.3\%) admitted to actions in the direct question but not the BBM, suggesting they did not understand, trust or feel comfortable with the BBM.

\subsection{Traded Jaguar Body Parts and their Uses}

The majority (78\%) of survey respondents were aware that jaguar body parts are traded and used in their communities, and were able to describe their uses (Table 1). The most commonly used jaguar body part was the skin, followed by jaguar fat, teeth, meat, claws and tails, skulls, live animals, bones and other jaguar body parts. Most body parts were locally used for decorative, medicinal, nutritional or cultural purposes. However, jaguar teeth, skulls and bones were also mentioned in the context of foreign demand. Three participants living near Trinidad had witnessed the preparation of 'jaguar 
paste' (gelatine made with jaguar bones and meat), while one participant near Rurrenabaque had seen refrigerators filled with jaguar corpses at the residence of an Asian trader. Participants also commented on the methods used to kill jaguars (Appendix S3) and the prices of jaguar body parts (Appendix S4), which varied widely for all items.

\subsection{Actors in the jaguar body part trade:}

151

152

Sixty seven percent of participants were aware of the existence of jaguar traders in and around their communities and were able to comment on their characteristics and interactions with them (Table 2). Forty three percent of respondents reported that Bolivian nationals (local or from major cities) traded jaguar body parts. Some participants who had been personally approached by Bolivian traders reported that they were young males acting as intermediaries to Asian foreigners. Seventeen participants from our Trinidad study area mentioned that jaguar body parts are sold to local prisons, where convicts use them to make crafts to pay for prison fees. During an ad hoc visit to the 'El Campesino' market in Trinidad on August 2019, we were able to confirm the presence of these crafts, and sellers said that these came from prisons in Beni.

The next most prevalent trader group was people of Asian descent, which included mainly Chinese nationals but also Japanese, Korean and Thai people. Asian buyers, some of whom were described as workers at Chinese infrastructure companies or long-term residents in Bolivia approached villagers directly, speaking Spanish or with the help of a translator. Nine percent of participants had had direct interactions with Asian people, and $29 \%$ of those interactions specifically involved jaguar trade. Another $4.5 \%$ of participants mentioned that someone else in their community had been approached by Asian jaguar traders. Asian traders also requested other species, particularly snakes, 
caiman, psittacines, and dogs. Participants provided details about their perceptions towards Asian people (Appendix S5).

Caucasian-looking foreigners, described as tourists, wildlife collectors and religious missionaries were the next most mentioned traders, followed by regional foreigners from Latin American countries (including Brazil, Peru, Argentina, Chile, Paraguay, Venezuela, and Colombia). Some participants mentioned that the requests for jaguar body parts came from radio advertisements asking people to deposit the items at specific locations such as hotels in urban centres; while others said that university students of both Chinese and Bolivian nationality had been purchasing jaguar bones and skulls to conduct a study on the strength of the jaguar.

Even though Bolivians were the most often-mentioned traders, awareness of the existence of regional and Caucasian traders increased participants' odds of engaging in almost all jaguar killing and trading actions (Table 3). Conversely, awareness of the existence of Asian traders only played a significant role in increasing the likelihood of being asked to kill a jaguar, selling jaguar body parts, and asking others to kill a jaguar; while awareness of Bolivian traders was only significantly associated with ownership of jaguar body parts.

\section{Discussion}

We found that jaguar killing and trading is a common and non-sensitive activity throughout our study areas. While recent seizures of jaguar body parts linked to Chinese demand raised awareness about jaguar trade in Bolivia, one of the most significant outcomes of our study was the scale of domestic possession, use, and trade in jaguar body parts. Bolivians were not only the most mentioned traders, but local ownership of jaguar body parts and awareness of their traditional uses, 
was higher than we anticipated. This may be indicative of poor law awareness and enforcement, or a reflection of a problematic interpretation of laws concerning wildlife use in the country, which prohibit the trade of nationally protected species like the jaguar, while also granting traditional wildlife use rights to indigenous communities (Bolivian Constitution 2009). This may have led some of our participants, who were predominantly non-indigenous; to believe that laws protecting jaguars and other wildlife did not apply to them. Moreover, the use of jaguar body parts appeared to be engrained in rural people's cultural practices, from typical dances to therapeutic beliefs and hunting identities. Local uses and traditional beliefs have also been identified as an important threat for other felid species throughout the world (Alves et al. 2013; Williams et al. 2017a).

Another noteworthy finding was the presence of non-Asian foreign traders, including Caucasians and people from other countries in the region, and its association to participants' engagement with jaguar trade. This had already been suggested by studies on the links between tourism and jaguar trade in other countries (Braczkowski et al., 2019; Reuter et al., 2018), but our results indicate that jaguar trade in Bolivia may be more international in scope than originally thought. It is worth considering that Europe and North America, like Asia, are important IWT demand regions for a range of taxa (Rosen \& Smith 2010), and that their nationals' interest in purchasing jaguar items has been reported in recent years in countries like Costa Rica (Kelly 2018).

As expected, given recent seizure events in Bolivia, we corroborated the involvement of Asian citizens in jaguar trade. In addition to teeth, Asian traders in our study areas were reportedly also interested in buying jaguar skulls and bones, suggesting that jaguar paste may be being made in Bolivia as a substitute for tiger paste in traditional Asian medicines, as has been documented for the case of Surinam (Verheij 2019; Lemieux \& Bruschi 2019). As China's international cultural influence and investments expand across the world through the Belt and Road Initiative, there are increasing 
concerns about its potential risks to wildlife overseas, and particularly to species that are used in Traditional Chinese Medicine, such as big cats (Farhadinia et al. 2019; Hinsley et al. 2019). Although the connection between Chinese foreign investments and wildlife trade still lacks supporting evidence, there are some examples of in-country Chinese demand for bushmeat and high value items like elephant ivory and rhino horn in several African countries (Cao \& Cao 2015; Mambeya et al. 2018). However, given the small number of participants who mentioned jaguar paste in our surveys, we recommend more research in Bolivia into the Asian medicinal market for jaguar body parts, as well as the role of Chinese companies and students in jaguar trade.

The wider significance of these findings is that counter-trade interventions for jaguars and other felids need to disentangle domestic and international forms of trade, and consider local behaviours and cultural drivers. Our results reinforce the message of Margulies et al., (2019), of moving beyond mainstream discourses in IWT, such as that of the "Asian super-consumer", which may deflect focus away from the diversity of players and complex feedbacks between IWT drivers across scales, including in source areas.

\section{Acknowledgements}

We thank our funders: San Diego Zoo's Institute for Conservation Research, the Rufford Foundation, the Wildlife Conservation Network, the Society of American Mammalogists, the Society for Conservation Biology, St. Cross College, SENESCYT, and FCT/MCTES - CESAM (UID/AMB/50017/2019). We thank Asociación Boliviana para la Investigación y Conservación de Ecosistemas Andino-Amazonicos (ACEAA) and J. Zapata-Munoz and M. Fernandez for their contribution to data collection. We thank F. Arana-Meira for support with fieldwork planning, research design and data analysis. We thank the University of Oxford's Social Sciences and 
241 Humanities Research Ethics Committee for granting us ethical approval (Reference: R63986/RE001),

242 and the Bolivian Ministry of Environment and the Museum of Natural History of La Paz for research

243 permits (Ref: MMAYA/VMABCCGDF/DGBAP/MEG No. 0251/2019). The data for this research is not

244 available due to confidentiality. This paper is a product of the Oxford Martin Programme on Illegal

245 Wildlife Trade.

246 
Alves RRN, Pinto LCL, Barboza RRD, Souto WMS, Oliveira REMCC, Vieira WLS. 2013. A global overview of carnivores used in traditional medicines. Pages 171-206 Animals in Traditional Folk Medicine: Implications for Conservation. Springer-Verlag Berlin Heidelberg.

251

Bates D, Maechler M, Bolker B, Walker S. 2015. Fitting Linear Mixed-Effects Models Using Ime4. Journal of Statistical Software 67:1-48.

Bolivian Constitution. 2009. Political Constitution of the State of Bolivia 2009. La Paz.

Bova CS, Aswani S, Farthing MW, Potts WM. 2018. Limitations of the random response technique and a call to implement the ballot box method for estimating recreational angler compliance using surveys. Fisheries Research 208:34-41. Elsevier.

Braczkowski A, Ruzo A, Sanchez F, Castagnino R, Brown C, Guynup S, Winter S, Gandy D, O’Bryan C. 2019. The ayahuasca tourism boom: An undervalued demand driver for jaguar body parts? Conservation Science and Practice 1. Wiley.

Cao D, Cao D. 2015. Crouching Tiger Bones, Hidden Elephant Tusks: Wildlife Crimes. Pages 65-99 Animals in China. Palgrave Macmillan UK.

Castaño-Uribe C et al. 2017. II. Conflictos entre felinos y humanos en América Latina. Instituto de Investigación de Recursos Biológicos Alexander von Humboldt.

Coghlan ML et al. 2015. Combined DNA, toxicological and heavy metal analyses provides an auditing toolkit to improve pharmacovigilance of traditional Chinese medicine (TCM). Scientific Reports 5:1-9. Nature Publishing Group.

D’Cruze N, Macdonald DW. 2015. Clouded in mystery: the global trade in clouded leopards. Biodiversity and Conservation 24:3505-3526. Springer Netherlands.

Davis EO, Willemsen M, Dang V, O'Connor D, Glikman JA. 2020. An updated analysis of the 

consumption of tiger products in urban Vietnam. Global Ecology and Conservation 22:e00960. Elsevier B.V.

272

Devleesschauwer B, Torgerson P, Johannes Charlier B, Levecke N, Praet S, Roelandt S, Smit P, Speybroeck D, Berkvens D, Speybroeck N. 2014. prevalence: Tools for prevalence assessment studies. R package version 0.4.0.

Farhadinia MS, Maheshwari A, Nawaz MA, Ambarlı H, Gritsina MA, Koshkin MA, Rosen T, Hinsley A, Macdonald DW. 2019, September 1. Belt and Road Initiative may create new supplies for illegal wildlife trade in large carnivores. Nature Publishing Group.

Hinsley A, Milner-Gulland EJ, Cooney R, Timoshyna A, Ruan X, Lee TM. 2019. Building sustainability into the Belt and Road Initiative's Traditional Chinese Medicine trade. Nature Sustainability 3:96-100. Nature Research.

Jędrzejewski W et al. 2017. Human-jaguar conflicts and the relative importance of retaliatory killing and hunting for jaguar (Panthera onca) populations in Venezuela. Biological Conservation 209:524-532. Elsevier.

Kelly JR. 2018. Insights into the illegal trade of feline derivatives in Costa Rica. Global Ecology and Conservation 13:e00381.

Knox J, Negrões N, Marchini S, Barboza K, Guanacoma G, Balhau P, Tobler MW, Glikman JA. 2019. Jaguar Persecution Without "Cowflict": Insights From Protected Territories in the Bolivian Amazon. Frontiers in Ecology and Evolution 7:494. Frontiers Media S.A.

Lemieux AM, Bruschi N. 2019. The production of jaguar paste in Suriname: a product-based crime script. Crime Science 8:6.

Macdonald DW, Loveridge AJ. 2010. The biology and conservation of wild felids. Oxford University Press, Oxford. 
Mambeya MM et al. 2018. The emergence of a commercial trade in pangolins from Gabon. African Journal of Ecology 56:601-609. Blackwell Publishing Ltd.

Margulies JD, Wong RWY, Duffy R. 2019. The imaginary 'Asian Super Consumer': A critique of demand reduction campaigns for the illegal wildlife trade. Elsevier Ltd.

Matos F, Caldarelli CE. 2017. Liberdade na Pele: Gateiros e o Comercio de Peles de Fantasia no Baixo Xingu (Décadas de 1960-70). Page XXIX Simposio de Historia Nacional. Contra os Preconceitos: Historia e Democracia. Brasilia.

Milner-Gulland EJ, Cugniere L, Hinsley A, Phelps J, 't Sas Rolfe M, Verissimo D. 2018. Evidence to Action: Research to Address Illegal Wildlife Trade. Oxford.

Nijman V, Morcatty T, Smith JH, Atoussi S, Shepherd CR, Siriwat P, Nekaris KAI, Bergin D. 2019. Illegal wildlife trade-surveying open animal markets and online platforms to understand the poaching of wild cats. Biodiversity 20:58-61. Taylor and Francis Ltd.

Nowell K. 2010. Tiger Farms and Pharmacies: The Central Importance of China's Trade Policy for Tiger Conservation. Pages 463-475 Tigers of the World. Elsevier Inc.

Nunez AM, Aliaga-Rossel E. 2017. Jaguar fangs trafficking by Chinese in Bolivia. CAT News 65.

Nuno A, St. John FAV. 2015. How to ask sensitive questions in conservation: A review of specialized questioning techniques. Biological Conservation 189:5-15. Elsevier.

R Core Team. 2019. R: A language and environment for statistical computing. R Foundation for Statistical Computing, Vienna, Austria.

Reuter A et al. 2018. Jaguar Hunting and Trafficking in Mesoamerica Recent Observations.

Rosen GE, Smith KF. 2010. Summarizing the Evidence on the International Trade in Illegal Wildlife. EcoHealth 7:24-32. 

of the World. Elsevier Inc.

317 Stein A. et al. 2016. Panthera pardus. The IUCN Red List of Threatened Species 2016. Page View on www.iucnredlist.org Citation.

T Sas-Rolfes M, Challender DWS, Hinsley A, Veríssimo D, Milner-Gulland EJ. 2019. Illegal Wildlife Trade: Scale, Processes, and Governance. Annual Review of Environment and Resources 44:201-228. Annual Reviews.

Verheij P. 2019. An Assessment of Wildlife Poaching and Trafficking in Bolivia and Suriname. Amsterdam.

Villalva P, Moracho E. 2019, May 24. Tiger trade threatens big cats worldwide. NLM (Medline).

WCS. 2019. Evidencias del tráfico de partes de jaguar en la Amazonía peruana. Lima.

Williams VL, Loveridge AJ, Newton DJ, Macdonald DW. 2017a, October 1. Questionnaire survey of the pan-African trade in lion body parts. Public Library of Science. of Science. 
333 Table 1: Jaguar body part uses in participant's communities, described by percentage of participants

334 in the sample $(n=1107)$ who mentioned each part and use.

\begin{tabular}{|c|c|c|c|}
\hline $\begin{array}{l}\text { Body } \\
\text { Part }\end{array}$ & $\begin{array}{l}\text { Use } \\
\text { Category }\end{array}$ & $\begin{array}{l}\text { Percentage } \\
\text { of Sample }\end{array}$ & Use detail \\
\hline \multirow{3}{*}{ Skin } & Decorative & 53.7 & $\begin{array}{l}\text { Home decoration: tapestries, rugs, chairs, hammocks; personal } \\
\text { accessories: belts, wallets, purses, hats, shoes, saddles, briefcases }\end{array}$ \\
\hline & Cultural & 5.3 & Costumes and drums for traditional dances \\
\hline & Medicine & 0.3 & Treatment for headaches (by burning the pelt) \\
\hline \multirow[t]{2}{*}{ Fat } & Medicine & 35.9 & $\begin{array}{l}\text { Rubbing ointment: rheumatism, arthritis, welling, muscle pain, } \\
\text { cramping, burnt or inflamed skin, varicose veins, complicated child } \\
\text { births; Drinking syrup: common cold, pneumonia, embolism, } \\
\text { asthma, bronchitis, uric acid, kidney disease }\end{array}$ \\
\hline & Repellent & 5.2 & $\begin{array}{l}\text { Repellent for crop-raiding animals (by scattering the fat in crops); to } \\
\text { keep cattle in their corrals; to manage untamed cattle }\end{array}$ \\
\hline \multirow{3}{*}{ Teeth } & Decorative & 24.3 & Jewellery and key chains; sold to locals and foreigners \\
\hline & Medicine & 1.9 & $\begin{array}{l}\text { Treatment for facial paralysis caused by a spell of misfortune (by } \\
\text { grinding and burning the teeth); dental fillings }\end{array}$ \\
\hline & Cultural & 0.9 & $\begin{array}{l}\text { Necklaces worn at traditional festivals; amulets to protect against } \\
\text { bad luck or evil spirits }\end{array}$ \\
\hline \multirow{2}{*}{ Meat } & Nutrition & 20.6 & Food for humans and domestic animals like dogs \\
\hline & Cultural & 0.4 & Consumed for vitality and strength, particularly amongst hunters \\
\hline \multirow{2}{*}{$\begin{array}{l}\text { Tail \& } \\
\text { Claws }\end{array}$} & Decorative & 16.9 & Jewellery and key chains; recipients to hold small objects (paws) \\
\hline & Cultural & 1.5 & Amulet for good luck and strength \\
\hline \multirow{4}{*}{ Skull } & Decorative & 13.4 & Trophies; painted and turned into lamps; sold to foreigners \\
\hline & Cultural & 2.3 & Amulet for good luck in business; witchcraft; traditional dance masks \\
\hline & Repellent & 0.3 & Repellent for crop raiding animals; prevents encounters with jaguars \\
\hline & Studies & 0.8 & Purchased by students to conduct studies on jaguar strength \\
\hline Live & Pets & 6.1 & Pets; attractions for zoos or circuses \\
\hline \multirow{4}{*}{ Bones } & Medicine & 0.9 & Medicine for strength; sell to foreigners \\
\hline & Cultural & 0.7 & Kept at home for luck; keeps thieves away \\
\hline & Studies & 0.5 & Purchased by students to conduct studies on jaguar strength \\
\hline & Repellent & 0.2 & Repellent for crop raiding animals \\
\hline \multirow{3}{*}{ Others } & Medicine & 0.6 & Eyes are used as a treatment for poor eyesight \\
\hline & Cultural & 0.3 & Brain and heart are used for rituals \\
\hline & Other & 0.1 & Whiskers and penis can be sold to foreigners \\
\hline
\end{tabular}


Table 2: Jaguar body part trader types, and the percentage of respondents mentioning these people.

337 Total percentage is $>100 \%$ as people could mention multiple trader types. Total sample size $=1107$.

338

\begin{tabular}{clc}
\multicolumn{1}{c}{ Actions } & \multicolumn{1}{c}{ Characteristics } & Percentage of Total Sample \\
\hline \multirow{3}{*}{$\begin{array}{c}\text { Actors who request jaguar } \\
\text { body parts }\end{array}$} & Bolivian & 42.6 \\
& Asian & 20.1 \\
& Caucasian & 14.5 \\
& Regional & 5.9 \\
& Radio advertisements & 3.3 \\
& Universities/Students & 2.4 \\
\hline Participants who had & No & 91.2 \\
interacted with Asians & Yes & 8.9 \\
\hline \multirow{2}{*}{ Sources of information } & Unaware & 79.9 \\
about Asians purchasing & Word of Mouth & 13.1 \\
jaguar body parts & Family and Community & 4.5 \\
& Personal & 2.5 \\
\hline
\end{tabular}

Table 3: Odds Ratios of the association between a respondent being aware of the existence of a

341 jaguar killing or trading action. Estimates based on a mixed effect binomial GLM, with community

342 and study area as random effects. Values above and below one indicate whether traders are $p<0.001, * *=p<0.01, *=p<0.05)$.

Jaguar Killing and Trading Actions

\begin{tabular}{|c|c|c|c|c|c|c|c|c|}
\hline Traders & $\begin{array}{l}\text { Raised } \\
\text { Live } \\
\text { (n=1053) }\end{array}$ & $\begin{array}{l}\text { Owned } \\
\text { Body } \\
\text { Parts } \\
(n=1064)\end{array}$ & $\begin{array}{l}\text { Bought } \\
\text { Body } \\
\text { Parts } \\
(n=1054)\end{array}$ & $\begin{array}{l}\text { Been } \\
\text { Asked to } \\
\text { Kill } \\
(n=1057)\end{array}$ & $\begin{array}{l}\text { Killed } \\
(n=1055)\end{array}$ & $\begin{array}{l}\text { Killed>5 } \\
(n=1049)\end{array}$ & $\begin{array}{l}\text { Sold } \\
\text { Body } \\
\text { Parts } \\
(n=1054)\end{array}$ & $\begin{array}{l}\text { Asked } \\
\text { Others } \\
\text { to Kill } \\
(n=1044)\end{array}$ \\
\hline Asian & 0.71 & 1.34 & 1.19 & $2.22 * * *$ & 0.96 & 1.77 & $2.09 * * *$ & $1.53^{*}$ \\
\hline Caucasian & $3.44 * * *$ & $2.19 * * *$ & $2.41 * * *$ & $2.37 * * *$ & $2.25^{* * *}$ & 1.44 & $3.18^{* * *}$ & $1.92 * *$ \\
\hline Regional & $4.88 * * *$ & $2.47 * *$ & $3.00 * * *$ & 1.68 & 1.24 & 0.55 & $2.38^{*}$ & 1.75 \\
\hline Bolivian & 0.84 & $1.41 *$ & 0.86 & 0.95 & 1.23 & 1.29 & 0.82 & 1.18 \\
\hline
\end{tabular}




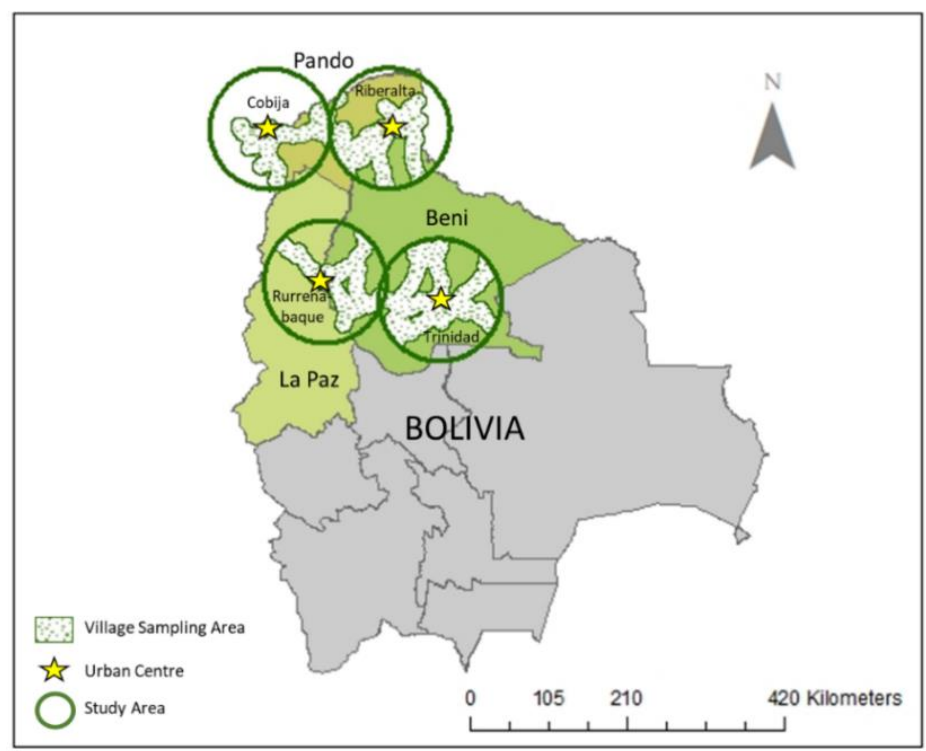

Figure 1: Map of Study Areas in north-western Bolivia, based on a prioritisation of rural lands around

the main urban areas in the Departments of Beni, Pando and northern La Paz

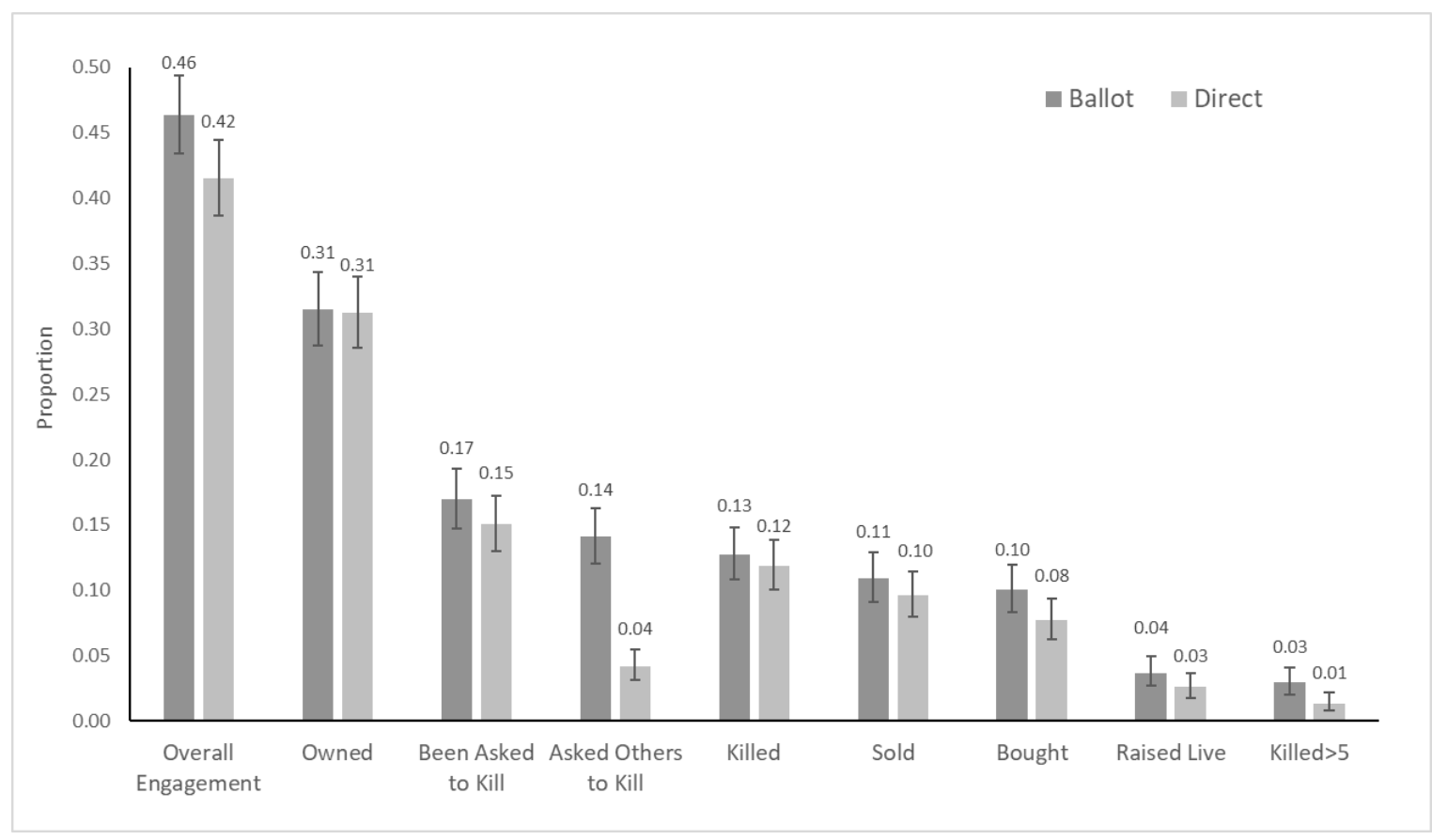

351 Figure 2: Proportion of participants that engaged in jaguar killing and trading actions in our study

352 areas. Sample size varies per question, ranging from 1044 to 1064 participants who answered both

353 directly and through the ballot box method (BBM). 95\% confidence intervals calculated using the Jeffrey's interval method for binomial proportions. 